\title{
Amin Samman
}

City University London, UK

\section{Nathan Coombs}

University of Edinburgh, UK

\section{Angus Cameron}

University of Leicester, UK

\section{Finance studies in and after crisis}

The financial crisis of 2007-8 sparked a variety of responses from elites and popular movements across the world. Its legacy also continues to shape capitalist societies through ongoing processes of regulatory reform, state restructuring, and financial innovation. While these processes are open-ended, they are increasingly subject to critical attention from a range of commentators. The usual suspects are out in force - academics, politicians, and pundits - but they are now joined by a wider array of theorists and activists, playwrights, novelists and artists. The financialisation of capitalism, it seems, has finally been met with a blooming of the financial imagination. Finance and Society will provide a space for the further development of this imagination, generating new insights into how money and finance organise social life.

The power of finance has been one of the basic lessons to emerge from the recent crisis. After the bankruptcies of once-prestigious institutions, debates have raged over risk-taking in the financial sector, exorbitant bonuses, and the broader implications of public sector bailouts. Yet for all the moral opprobrium heaped upon 'greedy bankers' for their part in causing the crisis, financial phenomena frequently appear (or are presented) as abstract, opaque, even mystical forces buffeting our world. Financial wizards craft new and ever more complex instruments, market participants deal in a myriad of exotic derivatives, and central bankers unleash spells of quantitative easing. Amidst all this numerical magic, the language of finance only further serves to bewitch the interested publics upon whom finance ultimately works. Even governments speak in financial tongues. Politicians routinely invoke shifting winds in the bond markets when gouging public services. They also, it must be said, engage in financial engineering and innovative accounting of their own. At the time of writing, for instance, the London Review of Books carries an article on the planned sale of the UK's pre-2012 student loan book (McGettigan, 2015). The uncertain valuation of the loan book has forced the 
Treasury to invent a 'synthetic hedge' to put potential investors at ease (by making the British taxpayer assume the risk). That the sell-off will be loss making over the long term but beneficial over the short term electoral cycle is predicated on the opacity of the financial manoeuvres involved. Hence the challenge posed by finance today - never before has an array of such complex financial processes been so integral to the structuring of society, yet as a society we remain no closer to an understanding of finance that might bring it within the sphere of true democratic accountability.

A new form of finance studies fit to meet this challenge is already emerging. Once the preserve of neoclassical economists, questions relating to finance now animate scholars working within a range of disciplines, from literary criticism and historical study all the way through to political economy (e.g. Knight, 2013; Carico and Orenstein, 2014; Cooper and Konings, 2015; Crosthwaite et al., 2015; Green and Hay, 2015). These new approaches - in combination with methods from the more traditional economic and social sciences - are helping us better apprehend the social foundations and consequences of financial processes. In order to make good on this promise, however, the new finance studies must confront the disciplinary conventions within which it presently operates. The problem is that such conventions neither reflect the practices nor serve the interests of scholars studying finance and society. Among such scholars there is clearly an impulse to draw on the broadest possible range of intellectual resources, and yet when it comes to publishing, innovative research must still be funneled through the particularistic concerns of academic (sub-) disciplines. This journal will provide a platform dedicated to the exploration of questions that emerge from the social processes of finance itself, rather than the canons and genres through which their study has so far been conducted. In so doing it will push the new finance studies beyond unnecessary limits.

\section{Trading in concepts: On the limits to inter-disciplinary exchange}

If financial economists are losing their grip on the study of finance, then what are the parameters of the new finance studies? From the perspective of theory these appear as ambiguous, and perhaps even determinedly so. Everywhere scholars are challenging and overcoming old binaries, such as those that pit the sociological against the technological, the productive against the speculative, or the future-oriented against the contemporary. We agree that entanglements like these provide a powerful means of thinking finance otherwise. The problem is that we also see this enterprise as being hampered by the persistence of disciplinary divides and imperatives. Despite their best intentions, the new finance studies are structured around and by logics of inter-disciplinary exchange.

Take the 'social studies of finance' - an innovative approach to financial research that has risen to prominence since its inception at the turn of the millennium (Preda, 2001). This approach builds on a longer history on finance-related studies within economic sociology by drawing on insights from science and technology studies. In particular, the materialist constructivisms of Michel Callon (1998) and Bruno Latour (2005) have led a growing number of scholars to imagine markets as 'actor-networks' in which models, instruments, and practices all co-constitute the very nature of modern economies. This lens has advanced the study of finance in two key ways. First, it has revealed the power of financial theory to produce rather than merely reflect financial market dynamics. This is the now famous 'performativity' thesis, outlined with great detail and nuance in Donald MacKenzie's (2006) history of optionpricing models (see also MacKenzie et al., 2008; Muniesa, 2014). Its second key contribution 
has been to shine a spotlight on technical devices and those that employ them. With this has come a wave of empirical studies that supplement the notion of finance-in-general with a finegrained analysis of how market agents make and work with structured products, risk-valuation models, and high-frequency trading algorithms (MacKenzie and Spears, 2014; Lange and Borch, 2014). A further and related development is that approaches with little to do with science and technology studies have also been brought under the 'social studies of finance' banner. Anthropological studies have flourished, for instance, providing detailed ethnographies of financial innovation, regulation, and central bank policymaking (Lépinay, 2011; Riles, 2011; Holmes, 2013). As a programmatic intervention, then, the social studies of finance is thoroughly inter-disciplinary in character and has thus contributed to a reinvention of finance studies as we know it. There are limits, however, to the benefits a strictly inter-disciplinary paradigm can produce.

For an indication of these limits one need look no further than the aforementioned performativity thesis. As a broader approach to the study of markets, this is now not only "the dominant tendency in the social studies of finance" (Cooper and Konings, 2015: 249) but also an increasingly popular export to neighbouring disciplines. There has, for instance, been a notable uptake of the concept in critical security studies (Boy et al., 2011), in literary criticism (Stäheli, 2013), and in international political economy (Lockwood, 2014). This development is a double-edged sword. On one side, the 'performative turn' represents a basic challenge to conventional ontologies of finance and society. Such ontologies differ from one discipline to the next, and so it is only fitting that each translates the imported concept into disciplinespecific terms. The counter-side to this, however, is that conceptual innovations and empirical findings are dispersed across a range of disciplinary platforms and registers. The prospect for building on such innovations thus becomes tied to the emergence of sustained interdisciplinary exchange. This has yet to occur, with the consequence that important questions relating to the substance of the performativity thesis remain underexplored.

For example, what becomes of structural logics and forces after the performative turn? If economics is performative and economies are produced then does it make any sense to continue thinking about the 'capitalist' world? Callon (2007) has written on this briefly, concluding that the time has past for such totalising concepts. Yet beyond the social studies of finance, the question of how to characterise our economic system is very much a live one. In the last three years, a dialogue on Marx and Latour has been bubbling across journals in social theory, economic geography and international relations (see Roberts, 2012; Christophers, 2014; Koddenbrock, 2014). There has also been a drive to rethink foundational political economy categories such as money, debt, and value, be these in Marxian terms or otherwise (cf. Konings, 2011; Lazzarato, 2012; Bryan and Rafferty, 2013; Palan, 2013). Such questions are often overlooked in the social studies of finance's quest to explore the micro at ever-finer levels of granularity. Meanwhile, in political economy, the Marxist critique of performativity has yet to be wedded with a deeper reappraisal of the relation between contingency and foundation (on this see Cooper and Konings, 2015). These strands of literature have as much to gain from each other as the study of finance and society does from them. What they have lacked until now is a dedicated and open platform.

\section{Cultivating post-disciplinarity}

Finance and Society provides such a platform - an open-access and peer-reviewed journal dedicated to publishing innovative research on the entanglements of finance and society. This 
is a post-disciplinary enterprise not because we seek to do away with disciplined knowledge, but because we are convinced there is much to be gained by turning traditional disciplines from bodies of rules into pools of potential. In this we depart from the inter-disciplinary aspirations that grace so many a research tender.

To be inter-disciplinary is to work against but within disciplinarity - against, because a given coupling of disciplines is wagered to be worth more than the sum of its parts; but ultimately within, because these very calculations are based on the boundaries between existing disciplines. The post-disciplinary ethos is to work after and with the modern disciplines; to draw on theories and methods developed in different disciplinary contexts, but to do so in ways that might shed new light on evolving financial practices and the worlds these create. The worlds we actually inhabit, we must remember, are not disciplined, and so we should not expect constrained disciplinary approaches to explain them. Ours is therefore a puzzle and theme-driven approach, in which research and debate that emerges from the substance of finance itself is privileged over those that merely reflect the weight of accumulated academic tradition. To be for a post-disciplinary study of finance and society is therefore to be in favour of deep and pluralistic debate over the social foundations and consequences of contemporary finance.

In keeping with this overarching aim we have two ancillary goals for the journal. The first is to facilitate an extensive development of finance studies as a field. If present modes of interdisciplinary exchange see cutting-edge research dispersed across a range of platforms, then our aim is to provide a place where these diverse research agendas can come together. We therefore welcome and invite contributions from scholars working with concepts or methods from political economy and the social studies of finance, as well those who draw on more philosophical or aesthetic registers. Our second and related goal is to facilitate an intensive development of the field. In particular, we invite and encourage research that grapples with synergies and tensions between new trends in finance studies. This includes (but is by no means limited to) the question of foundation and structure within the performativity paradigm, which we highlighted above. How, for example, do representations of finance interact with the technical devices used by market participants and regulators, and what are the emergent structural properties of such interactions? The future of finance studies will be forged through questions like these, and we offer this journal as a site where more of them might be asked and answered.

\section{References}

Boy, N., Burgess, J.P., Leander, A. (2011) The Global Governance of Security and Finance: Introduction to the Special Issue. Security Dialogue, 42(2): 115-22.

Bryan, D. and Rafferty, M. (2013) Fundamental Value: A Category in Transformation. Economy and Society, 42(1): 130-53

Callon, M. (2007) What Does It Mean To Say That Economics Is Performative? In: Mackenzie, D., Muniesa, F. and Siu, L. (eds.) Do Economists Make Markets? On the Performativity of Economics. Princeton: Princeton University Press, 311-57.

Callon, M. (1998) Introduction: The Embeddedness of Economic Markets within Economic Theory. In: Callon, M. (ed.) The Laws of the Markets. Oxford: Blackwell Publishers, 1-57.

Carico, A. and Orenstein, D. (2014) Editors' Introduction: The Fictions of Finance. Radical History Review, 118: 3-13.

Christophers, B. (2014) From Marx to Market and Back Again: Performing the Economy. Geoforum, 57: 12-20. 
Cooper, M. and Konings, M. (2015) Contingency and Foundation: Rethinking Money, Debt, and Finance After the Crisis. South Atlantic Quarterly, 114: 239-50.

Crosthwaite, P., Knight, P. and Marsh, N. (2015) Economic Criticism. The Year's Work in Critical and Cultural Theory, DOI: 10.1093/ywcct/mbv005

Green, J. and Hay, C. (2015) Towards a New Political Economy of the Crisis: Getting What Went Wrong Right. New Political Economy, 20(3): 331-41.

Holmes, D.R. (2013) Economy of Words: Communicative Imperatives in Central Banks. Chicago: University of Chicago Press.

Knight, P. (2013) Introduction: Fictions of Finance. Journal of Cultural Economy, 6(1): 2-12.

Koddenbrock, K.J. (2014) Strategies of Critique in International Relations: From Foucault and Latour Towards Marx. European Journal of International Relations, DOI: 10.1177/1354066114538854

Konings, M. (2011) Money as Icon. Theory \& Event, 14(3): 1-14.

Lange, A. and Borch, C. (2014) Contagious Markets: On Crowd Psychology and High-Frequency Trading. Unpublished Manuscript.

Latour, B. (2005) Reassembling the Social: An Introduction to Actor-Network Theory. Oxford: Oxford University Press.

Lazzarato, M. (2012) The Making of the Indebted Man: An Essay on the Neoliberal Condition. Los Angeles: Semiotext(e).

Lépinay, V. (2011) Codes of Finance: Engineering Derivatives in a Global Bank. Princeton: Princeton University Press.

Lockwood, E. (2014) Predicting the Unpredictable: Value-at-Risk, Performativity, and the Politics of Financial Uncertainty. Review of International Political Economy, DOI: 10.1080/09692290.2014.957233

MacKenzie, D. (2006) An Engine, Not a Camera: How Financial Models Shape Markets. Cambridge: MIT Press.

MacKenzie, D., Muniesa, F. and Siu, L. (eds.) (2007) Do Economists Make Markets? On the Performativity of Economics. Princeton: Princeton University Press.

MacKenzie, D. and Spears, T. (2014) 'The Formula That Killed Wall Street': The Gaussian Copula and Modelling Practices in Investment Banking. Social Studies of Science, 44(3): 393-417.

McGettigan, A. (2015) Cash Today. London Review of Books, 37(5): 24-28.

Muniesa, F. (2014) The Provoked Economy: Economic Reality and the Performative Turn. London: Routledge.

Palan, R. (2013) The Financial Crisis and Intangible Value. Capital and Class, 37(1): 65-77.

Preda, A. (2001) Sense and Sensibility: Or, How Should Social Studies of Finance Be(have)? A Manifesto. Economic Sociology: European Electronic Newsletter, 2(2): 15-18.

Riles, A. (2011) Collateral Knowledge: Legal Reasoning in the Global Financial Markets. Chicago: University of Chicago Press.

Roberts, J.M. (2012) Poststructuralism Against Poststructuralism: Actor-Network Theory, Organizations and Economic Markets. European Social Theory, 15(1): 35-53.

Stäheli, U. (2013) Spectacular Speculation: Thrills, the Economy and Popular Discourse. Stanford: Stanford University Press. 